\title{
Impact of In-Ovo Injection of Folic Acid and Glucose on Hatchability, and Post-hatching Performance of Broiler Chickens
}

\author{
Amal Ahmed Abdel-Halim*, Fatma Rasmy Mohamed, Mohamed Abdel-Rahman El-menawey, and Hassan Bayoumi Gharib \\ Department of Animal Production, Faculty of Agriculture, Cairo University, 12613 Giza, Egypt \\ *Corresponding authors’ Email: amalelshemy33@agr.cu.edu.eg; (D) ORCiD: 0000-0003-4211-9221
}

\begin{abstract}
The present study was designed to investigate the impact of in-ovo injection of folic acid and glucose on hatching eggs from 55 weeks old broiler breeders. A total number of 900 hatching eggs were collected from Arbor Acres broiler breeders, then, eggs were divided into 6 groups including 1) Negative Control (non-injected, NC), 2) Dry Punch Control (pricked without injecting any solution, DPC), 3) Positive Control (eggs were injected with $0.5 \mathrm{~mL}$ normal saline, PC), 4) Folic Acid group (eggs were injected with $0.2 \mathrm{mg} /$ egg folic acid, FA), 5) Glucose group (eggs were injected with $125 \mathrm{mg} /$ egg glucose, Glu), and 6) Folic Acid with Glucose group (eggs were injected with $0.2 \mathrm{mg}$ folic acid with $125 \mathrm{mg} / \mathrm{egg}$ glucose, FA+Glu). Each treatment was divided into five replicates of 30 eggs each. Eggs were injected into the albumen under the air sac. After in-ovo injection, the eggs were stored for four days before hatching. After hatching, the chickens were reared in groups according to the treatments. All treatments were divided into 10 replications of 9 chickens in each. In-ovo injection with folic acid decreased the albumen $\mathrm{pH}$ significantly to 9.19 after 4 days of injection, while the negative control was 9.43 . Hatching quality was severely affected by all in-ovo injection treatments, but no significant differences were found between the treatment groups concerning the hatchability of fertile eggs. Injection treatments had no significant effect on the growth rate or the production number in any of the weeks. Injection of folic acid and (FA+Glu) significantly increased chickens' body weight at two and four weeks of age. Also, the dressing percentage when using folic acid and (FA+Glu) was significantly increased to $72.1 \%$ and $72.5 \%$, respectively, compared to the positive control group (68.3\%). In conclusion, our data suggested that in-ovo injection with a mixture of folic acid and glucose $(0.2 \mathrm{mg}$ folic acid +125 $\mathrm{mg} /$ egg glucose) could be used to enhance carcass characteristics. Further studies should be conducted to find the effects of in-ovo injection folic acid and glucose on different incubation days and at different sites of injection.
\end{abstract}

Keywords: Broilers, Folic Acid, Glucose, Hatchability, In- Ovo injection, Old breeders, Post-hatch

\section{INTRODUCTION}

A range of healthy chickens with high growth ability and viability is very important to the poultry industry. The age of broiler breeder is one of the most important factors affecting hatchability and chickens' quality. The eggs of old breeders have a lower fertility and hatchability than those of the young breeder (Elibol et al., 2002; Vieira et al., 2005; Iqbal et al., 2016). Previous studies showed that the low incidence of hatchability in eggs of older breeders was due to many contributing factors, such as a poorer eggshell quality due to the larger surface (Bennett, 1992), and the deterioration in the albumen quality (Tona et al., 2004).

Older breeders' eggs were associated with larger size and thinner shells with higher porosity, which had been associated with a higher percentage of egg moisture loss during incubation. This increased mortality in the early phase of embryogenesis due to dehydration (Peebles et al., 2001), led to poor hatching quality (Narushin and Romanov, 2002). With increasing age of the breed, the albumen $\mathrm{pH}$ increased at oviposition, which may be due to the faster release of $\mathrm{CO}_{2}$ through the eggshell due to a higher eggshell porosity (Meijerhof, 1994). There seems to be an association between albumen $\mathrm{pH}$ before incubation and viability of embryo during early phase of embryogenesis, an albumen $\mathrm{pH}$ of 8.2 appears to be optimal for embryogenesis (Reijrink et al., 2008). Lapao et al. (1999) found that most of the rise in albumen $\mathrm{pH}$ occurred during the first four days of storage.

At hatching, older breeders were associated with an increase in day-old chicken weight and a decrease in chick quality (Koppenol et al., 2015). Also, the chickens from an old breeder were less feed efficient (higher FCR) than the chickens from the young breeder (Ulmer-Franco et al., 2010).

In recent years, much attention has been paid to the field of in-ovo injection. In-ovo technology is a method that can potentially enhance the hatchability and post-hatch performance of broiler chickens (Zhang et al., 2019). With Inovo technology, various substances were injection into the air chamber or directly into the egg (Kucharska-Gaca et al., 2017). Various factors influenced the effectiveness of in-ovo injection, including the injection site, the stage of development of the embryo, the level of contamination in the hatchery, and the in-ovo injection equipment (Ricks et al., 
1999). Various nutrients were examined for effectiveness in improving embryonic development, hatchability, and posthatch performance including carbohydrates, amino acids, peptides, electrolytes and vitamins (Kucharska-Gaca et al., 2017). The effectiveness of in-ovo injection methodology on hatching quality is still under study due to the optimum site and time of injection and the suitable volume and nutrient of injected solution (Tasharofi et al., 2018). Folic acid is a critical vitamin during reproduction and the hatching requirement is higher compared to egg production (Vieira, 2007). Folate was essential for embryonic development, regardless of whether in-ovo feeding of folic acid could influence the growth performance (Li et al., 2016). Parnian et al. (2019) found that in-ovo injection of folic acid improvement the body weight of the chickens.

Embryonic blood plasma glucose concentrations reduced with increasing age of the breeder (Christensen et al., 1996). Glucose or dextrose is a simple sugar that is used by cells as an essential source of energy and a metabolic intermediate, and is the most important source of energy for embryonic development (Starck and Ricklefs, 1998). Therefore, the aim of this work was to investigate if the in-ovo injection of folic acid and glucose into eggs of old broiler breeders could be useful for improving hatchability and post-hatching productivity.

\section{MATERIALS AND METHODS}

\section{Ethical approval}

The present study has been conducted in accordance with the guidelines of the Ethics Committee of the Faculty of Agriculture of Cairo University. The experimental fieldwork was carried out in the Agriculture Experimental Station of the Faculty of Agriculture- Cairo University in Giza, Egypt.

\section{Structure}

A total number of 900 hatching eggs were collected from Arbor Acres broiler parents at 55 weeks of age. The eggs were prepared at El Ahlia hatchery, El Ahlia Poultry Company, Tanta city, Egypt. . The eggs were randomly divided into six treatments group (150 eggs each) four days before incubation; each group was divided into five replicates (30 eggs each). The treatments consisted of (1) Negative Control, in which no eggs were injected (NC), (2) Dry Punch Control, in which shell and shell membranes were pricked without injecting any solution (DPC), (3) Positive Control, in which eggs were injected with $0.5 \mathrm{~mL}$ normal saline (PC), (4) Folic Acid group, in which eggs were injected with $0.5 \mathrm{~mL}$ normal saline containing $0.2 \mathrm{mg}$ folic acid (FA), (5) Glucose group, in which eggs were injected with $0.5 \mathrm{~mL}$ normal saline containing $125 \mathrm{mg}$ glucose (Glu) and (6) Folic acid with Glucose group, in which eggs were injected with $0.5 \mathrm{~mL}$ normal saline contain $0.2 \mathrm{mg}$ folic acid and $125 \mathrm{mg}$ glucose $(\mathrm{FA}+\mathrm{Glu})$. The eggs were injected in the albumen under the air sac.

\section{In-ovo injection}

At the time of injection, the large ends of the freshly laid eggs were cleaned with ethyl alcohol (70\%) and were penetrated by a pin, taking care not to injure the outer egg membrane. The solutions were injected into the albumen ( 0.5 $\mathrm{mL} / \mathrm{egg}$ ) at a depth of $12 \mathrm{~mm}$ (Akhlaghi et al., 2013), via a disposable syringe (1 ml syringe). The punched eggs were sealed with melted paraffin wax, then were given an identification number and stored for four days $\left(18^{\circ} \mathrm{C}\right.$ and $75 \%$ relative humidity $(\mathrm{RH})$ ) until the end of incubation. Two eggs from each replicate were randomly selected to evaluate the albumen $\mathrm{pH}$ before injection and after two to four days of injection. The $\mathrm{pH}$ of egg albumen was measured $\mathrm{using}$ a $\mathrm{pH}$ meter at room temperature. The measured $\mathrm{pH}$ of all solutions was 7.23, 3.98, 4.08, and 3.46 for sodium chloride, folic acid, glucose and the combination of folic acid and glucose, respectively.

\section{General Management}

All eggs were set in an incubator at average temperature of $37.5^{\circ} \mathrm{C}$, and relative humidity of $56.5 \%$. The eggs were turned hourly. At 444 hours of incubation, the eggs were transferred to a hatcher at an average temperature of $36.6^{\circ} \mathrm{C}$, and a relative humidity of $61.2 \%$. After hatching, all unhatched eggs were examined to calculate the embryonic mortality, which was classified as unfertile and early mortality (1-12 days) and late embryo mortality (13-21days). Total embryonic mortality was determined as the amount of the all dead embryos. Other calculated parameters consisted of fertility percentage, hatchability of total eggs and hatchability of fertile eggs. Fertility percentage was calculated as (number of fertile eggs divided by number of total eggs) multiply by 100. Hatchability of total eggs calculated as (number of hatched chicks divided by number of total eggs) multiply by 100. Hatchability of fertile eggs calculated as (number of hatched chicks divided by number of fertile eggs) multiply by 100

After hatching, 540 chickens were then transported to the farm of the Faculty of Agriculture Cairo University. Each treatment was divided into ten replicates (Nine chickens each). Each replicate was housed separately in several cages in semi-closed system house. 
Feed and water were available ad libitum. Chickens received a commercial broiler starter diet with $3025 \mathrm{kcal}$ of $\mathrm{ME} / \mathrm{kg}$ and $23 \%$ Crude Protein (CP) from first to $14^{\text {th }}$ day. At the age of 14 to 28 days, the chickens were fed a grower diet with $3150 \mathrm{kcal}$ of $\mathrm{ME} / \mathrm{kg}$ and $21 \% \mathrm{CP}$. From 28 days to 35 days of age, the chickens were fed a finisher diet containing $3200 \mathrm{kcal}$ of ME/kg and $19 \% \mathrm{CP}$. Starter feed was provided as crumbles, and subsequent feeds were provided as pellets.

\section{Measurements}

The live body weights of chickens were recorded individually weekly from day one to five weeks of age. The weekly feed intake per replicate (g) was calculated and then the feed intake for chickens was calculated as the feed intake for each replicate within a certain time interval divided by the number of chickens in the same replicate during the same time period. Then it was divided into seven parts to calculate the daily feed intake. Feed conversion ratio calculated as the average feed consumption ( $\mathrm{g}$ ) for each replicate with a time period divided by the average body weight gain $(\mathrm{g}$ ) for the same replicate over the same period. Dead chickens were weighed to include their weight in the feed conversion estimates.

Growth rate (GR) was calculated according to the following:

$\mathrm{GR}=\mathrm{W} 2-\mathrm{W} 1 /[(\mathrm{W} 1+\mathrm{W} 2) / 2]$

Where, W1 refers to body weight at the beginning of a certain week and W2 to the body weight at the end of the same week.

The mortality rate was recorded daily and calculated as percentage for each replicate.

Production number: (Average kilograms of growth per day x (100-mortality \%) / FCR) x 100

To determine the carcass quality, ten chickens were randomly selected from each treatment at five weeks of age, weighed individually and slaughtered after eight hours fasting. After the blood was drawn, they were defeathered, processed, and eviscerated. Carcass yield (dressing, breast meat, and hind meat) was determined as a percent of the living body weight. Giblets (liver, heart, and gizzard), spleen, thymus, and bursa of fabricius were obtained.

\section{Statistical analysis}

The data were subjected to a one-way Analysis of Variance using the general linear model method of XLSTAT (2014) version 2014.5.03. In-ovo injection treatments were the main factor. Percentage data were subjected to arcsine transformation prior to the analysis. The mean values were compared using Duncan's multiple range test (Duncan, 1955) if there was a significant difference $(\mathrm{p} \leq 0.05)$. The model used was as follows: $\mathrm{Yjk}=\mu+\mathrm{Hj}+\mathrm{Ejk}$

Where: $Y j k=$ individual observation; $\mu=$ Overall mean; $\mathrm{Hj}=$ Effect of in-ovo injection treatments $(\mathrm{j}=1,2,3,4,5$, 6); Ejk = Residual error.

\section{RESULTS AND DISCUSSION}

\section{Albumen pH}

The effect of in-ovo injection treatments on albumen $\mathrm{pH}$ is presented in table 1. No significant differences in egg albumen $\mathrm{pH}$ were observed after two days post injection between any treatment groups. However, in all treatments, the albumen $\mathrm{pH}$ appeared to be too high when compared to previous researches. Akhlaghi et al. (2013) reported that the non-injected control was 8.67 after two days was 9.07 after four days of treatment. In our experiment, the albumen $\mathrm{pH}$ was 8.98 after two days and was 9.43 after four days. This may be due to the transport of eggs from the parents' farm to hatchery conditions was unsuitable. Four days after the injection, only folic acid could cause a significant $(p=0.037)$ decrease in the albumen $\mathrm{pH}$ from 9.43 in the negative control group to 9.19. This result may be due to the acidity of folic acid, folate $\mathrm{pH}<5$ (Combs and McClung, 2016), and the $\mathrm{pH}$ of the solution injected into eggs was 3.98. The recent results partly agreed with Ebrahimi et al. (2012), who found no differences in albumen $\mathrm{pH}$ due to injection of bicarbonate or phosphate buffer solutions injected into the albumen. Ebrahimi et al. (2012) stated that the volume of the buffer solutions, which had to optimally lower the albumen $\mathrm{pH}$, was too large, which could potentially be detrimental to the embryo.

\section{Embryonic mortality percentage}

The effects of in-ovo injection treatments on embryonic mortality and hatchability are presented in table 2 . All injection treatments increased early, late, and total embryonic mortality compared to the negative control, but the differences were not significant.

\section{Fertility and Hatchability}

There were no significant differences in the hatchability of fertile eggs between any of the injection groups. All treatments decreased either fertility or the hatchability of fertile eggs (Table 2). Hatchability of total eggs was also adversely affected by in-ovo injection, but the differences were only significant between the negative control and folic 
acid, glucose and the combination of folic acid and glucose. Folic acid, glucose and the combination of folic acid and glucose injection decreased the hatchability of fertile eggs to $76.4 \%, 75.4 \%$, and $73.9 \%$, respectively, compared to 91.0 $\%$ in the negative control. The results of the present study indicated that the albumen $\mathrm{pH}$ plays a minimal role in decreasing the hatchability. This is because the hatchability of the control eggs was high in eggs four days after injection where the albumen $\mathrm{pH}$ was high.

Table 1. Impact of in-ovo injection of folic acid and glucose into albumen in freshly laid eggs from Arbor Acres broiler breeders on albumen $\mathrm{pH}$ (means \pm Standard Error)

\begin{tabular}{|c|c|c|c|c|c|c|c|}
\hline Item & $\begin{array}{l}\text { Negative } \\
\text { control }\end{array}$ & $\begin{array}{l}\text { Dry punch } \\
\text { control }\end{array}$ & $\begin{array}{l}\text { Positive } \\
\text { control }\end{array}$ & $\begin{array}{c}\text { Folic acid } \\
(0.2 \mathrm{mg} / \mathrm{egg})\end{array}$ & $\begin{array}{c}\text { Glucose } \\
(125 \mathrm{mg} / \mathrm{egg})\end{array}$ & $\begin{array}{c}\text { Folic acid and Glucose } \\
(0.2 \mathrm{mg} \mathrm{FA}+125 \mathrm{mg} \\
\text { Glu /egg })\end{array}$ & $\begin{array}{c}\mathbf{p} \\
\text { value }\end{array}$ \\
\hline 2 days post injection & $8.98 \pm 0.05$ & $9.01 \pm 0.05$ & $8.94 \pm 0.05$ & $8.97 \pm 0.05$ & $8.94 \pm 0.05$ & $8.88 \pm 0.05$ & 0.4741 \\
\hline 4 days post injection & $9.43 \pm 0.05^{\mathrm{a}}$ & $9.35 \pm 0.05^{\mathrm{a}}$ & $9.36 \pm 0.05^{\mathrm{a}}$ & $9.19 \pm 0.05^{\mathrm{b}}$ & $9.36 \pm 0.05^{\mathrm{a}}$ & $9.31 \pm 0.05^{\mathrm{ab}}$ & 0.0367 \\
\hline
\end{tabular}

a,b; Means within a row followed by different superscripts differ significantly ( $\leq \leq 0.05)$. SE: Standard Error, FA: Folic Acid, Glu: Glucose

Table 2. Impact of in-ovo injection of folic acid and glucose into albumen in freshly laid eggs from Arbor Acres broiler breeders on embryonic mortality and hatchability (means \pm Standard Error)

\begin{tabular}{|c|c|c|c|c|c|c|c|}
\hline Item & $\begin{array}{l}\text { Negative } \\
\text { control }\end{array}$ & $\begin{array}{l}\text { Dry punch } \\
\text { control }\end{array}$ & $\begin{array}{l}\text { Positive } \\
\text { control }\end{array}$ & $\begin{array}{c}\text { Folic acid } \\
(0.2 \mathrm{mg} / \mathrm{egg})\end{array}$ & $\begin{array}{c}\text { Glucose } \\
(125 \mathrm{mg} / \\
\text { egg })\end{array}$ & $\begin{array}{c}\text { Folic acid and Glucose } \\
(0.2 \mathrm{mg} \mathrm{FA}+125 \mathrm{mg} \\
\text { Glu /egg })\end{array}$ & p value \\
\hline Non fertile (\%) & $12.1 \pm 2.6$ & $15.7 \pm 2.6$ & $18.6 \pm 2.6$ & $18.6 \pm 2.6$ & $18.6 \pm 2.6$ & $22.9 \pm 2.6$ & 0.1368 \\
\hline Early mortality (\%) & $2.9 \pm 2.2$ & $2.9 \pm 2.2$ & $9.3 \pm 2.2$ & $7.9 \pm 2.2$ & $10.0 \pm 2.2$ & $6.4 \pm 2.2$ & 0.1128 \\
\hline Late mortality (\%) & $5.0 \pm 2.6$ & $13.6 \pm 2.6$ & $8.6 \pm 2.6$ & $11.4 \pm 2.6$ & $10.0 \pm 2.6$ & $13.6 \pm 2.6$ & 0.1867 \\
\hline Total mortality (\%) & $7.9 \pm 3.4$ & $16.4 \pm 3.4$ & $17.9 \pm 3.4$ & $19.3 \pm 3.4$ & $20.0 \pm 3.4$ & $20.0 \pm 3.4$ & 0.1408 \\
\hline Apparent fertility (\%) & $87.9 \pm 2.6$ & $84.3 \pm 2.6$ & $81.4 \pm 2.6$ & $81.4 \pm 2.6$ & $81.4 \pm 2.6$ & $77.1 \pm 2.6$ & 0.1368 \\
\hline $\begin{array}{l}\text { Hatchability of fertile } \\
\text { eggs }(\%)\end{array}$ & $91.0 \pm 4.1$ & $80.3 \pm 4.1$ & $78.0 \pm 4.1$ & $76.4 \pm 4.1$ & $75.4 \pm 4.1$ & $73.9 \pm 4.1$ & 0.0811 \\
\hline $\begin{array}{l}\text { Hatchability of total eggs } \\
(\%)\end{array}$ & $80.0 \pm 4.2^{\mathrm{a}}$ & $67.9 \pm 4.2^{\mathrm{ab}}$ & $63.6 \pm 4.2^{\mathrm{b}}$ & $62.1 \pm 4.2^{\mathrm{b}}$ & $61.4 \pm 4.2^{\mathrm{b}}$ & $57.1 \pm 4.2^{b}$ & 0.0144 \\
\hline
\end{tabular}

$\overline{\mathrm{a}, \mathrm{b} ;}$ Means within a row followed by different superscripts differ significantly $(\mathrm{p} \leq 0.05)$. SE: Standard Error, FA: Folic Acid, Glu: Glucose

Ebrahimi et al. (2012), found that in-ovo injection of bicarbonate or phosphate buffer solutions before incubation decreased the hatchability of fertile eggs to $32.0 \%$ and $8.3 \%$ respectively, while the hatchability of fertile eggs in the controls was $87.5 \%$. In the present results, injection of glucose decreased the hatchability of fertile eggs, but may not be significant due to the organogenesis of important segments of the chicken embryo occur in the first week of embryonic development. Based on this information, in-ovo injection of glucose prior to this critical phase can be an effective stimulator for optimal organ development (Bellairs and Osmond, 2005). Ebrahimi et al. (2012) stated that decreases in hatchability of fertile eggs were due to the injected active ingredients which adversely affect the environment for the embryo. The $\mathrm{pH}$ or osmolality of the solutions could adversely affect the surrounding microenvironment of the early embryo. This could rationalize the numerically increased apparent fertility of the negative control in the results of the present study. The results of the present study were in part with Zhai et al. (2011b), who reported that the hatchability of fertile eggs was lower in eggs injected with glucose, fructose, maltose, sucrose, or dextrin, compared to the control group without injected, dry punch, and saline-injected control groups. However, Zhai et al. (2011a) stated that the hatchability of fertile eggs was not impaired by any injection treatment with Glucose, sucrose, maltose, or dextrin. Salmanzadeh et al. (2012) found that in-ovo injection with $75 \mathrm{mg}$ or $100 \mathrm{mg}$ glucose, dissolved in $0.5 \mathrm{~mL}$ deionized water after seven days of incubation into the albumen led to less hatchability than the negative control treatment. They stated that the decrease in hatchability could be due to the injection into the albumin under the air sac, which stopped the respiration in the developing embryo. Tasharofi et al. (2018) explained the decrease in hatchability in eggs injected with dextrose due to an overload of the energy metabolism in embryos due to the injection of high carbohydrate levels, which adversely affected hatchability. However, Zhang et al. (2016) found that the hatchability of eggs injected with glucose was very close to that of the negative control group. The results of the present research did not agree with Li et al. (2016) and Liu et al. (2016) found that in-ovo injection of $100 \mu \mathrm{g}$ or $150 \mu \mathrm{g}$ of folic acid (the injection volume in each egg was $0.1 \mathrm{ml})$ into the yolk sac after 11 days at embryonic age increased the hatchability compared to the control treatment $(0$ $\mu \mathrm{g}$ of folic acid). This may be attributed to the time difference or to the injection site.

On the other hand, Nouri et al. (2018) revealed that there was no significant difference in hatchability for eggs inovo, which had been injected with folic acid $(40,80$, and $120 \mu \mathrm{g})$ in albumen on day seven of incubation, compared to the negative control group and positive group (in-ovo injection of sterile water, $40 \mu \mathrm{g}$ ). Robel (2002) stated that hatchability in turkey eggs injected with folic acid at 25-day of incubation was not significantly affected compared to the 
negative control.

The discrepancy in the results may be due to the timing of the injection. The eggs were injected before incubation, so it was more susceptible to contamination. In-ovo injection, especially in early embryonic life, did not improve hatchability. It seems that in-ovo injection at the beginning of embryonic development could damage the internal environment of the egg and also have negative effects on hatchability (Salmanzadeh et al., 2012). The injection volume can also be too large. Zhai et al. (2011c) stated that the hatchability of fertile eggs was negatively related to the injection volume. Therefore, the in-ovo injection volume should be limited to prevent the embryo from becoming excessive hydrated and a subsequent decreasing hatchability. The effectiveness of in-ovo injection on hatchability is still not clear enough. The optimal site and time of injection as well as the volume of the injected solution and the appropriate nutrient have yet to be determined (Tasharofi et al., 2018).

\section{Post-hatch performance}

The in-ovo injection had no significant effect $(\mathrm{p}>0.05)$ on the body weight of chicken at hatching at one, three and five weeks of age (Table 3). However, a significant effect of the in-ovo injection treatment on body weight of the chicken at two and four weeks of age was observed. The body weight of chickens in the group injected with the combination of FA and Glu was the highest compared to the other injection treatments. However, the difference was not significant compared to the negative control. In-ovo injection with FA, Glu, and FA + Glu had no significant influence on the body weight of the chickens at hatching.

Table 3. Impact of in-ovo injection of folic acid and glucose into albumen in freshly laid eggs from Arbor Acres broiler breeders on body weight $(\mathrm{g})$ (means \pm Standard Error) of broiler chickens

\begin{tabular}{lccccccc}
\hline Age & $\begin{array}{c}\text { Negative } \\
\text { control }\end{array}$ & $\begin{array}{c}\text { Dry punch } \\
\text { control }\end{array}$ & $\begin{array}{c}\text { Positive } \\
\text { control }\end{array}$ & $\begin{array}{c}\text { Folic acid } \\
(0.2 \mathrm{mg} / \mathrm{egg})\end{array}$ & $\begin{array}{c}\text { Glucose } \\
(125 \mathrm{mg} / \mathrm{egg})\end{array}$ & $\begin{array}{c}\text { Folic acid and Glucose } \\
(0.2 \mathrm{mg} \text { FA+125 mg } \\
\text { Glu /egg })\end{array}$ & $\begin{array}{c}\text { p } \\
\text { value }\end{array}$ \\
\hline One day & $47.5 \pm 0.4$ & $47.7 \pm 0.4$ & $47.7 \pm 0.4$ & $48.6 \pm 0.4$ & $48.5 \pm 0.4$ & $48.2 \pm 0.4$ & 0.1671 \\
Week 1 & $173 \pm 1.9$ & $173 \pm 2.0$ & $170 \pm 2.1$ & $168 \pm 2.1$ & $168 \pm 2.1$ & $171 \pm 2.3$ & 0.2760 \\
Week 2 & $405 \pm 7.3^{\mathrm{ab}}$ & $387 \pm 7.8^{\mathrm{b}}$ & $406 \pm 8.2^{\mathrm{ab}}$ & $394 \pm 7.9^{\mathrm{b}}$ & $393 \pm 8.3^{\mathrm{b}}$ & $425 \pm 8.7^{\mathrm{a}}$ & 0.0233 \\
Week 3 & $892 \pm 13.8$ & $854 \pm 14.7$ & $864 \pm 15.4$ & $857 \pm 14.9$ & $855 \pm 15.6$ & $908 \pm 16.3$ & 0.0587 \\
Week 4 & $1527 \pm 22.2^{\mathrm{a}}$ & $1447 \pm 23.6^{\mathrm{b}}$ & $1456 \pm 25.0^{\mathrm{b}}$ & $1461 \pm 24.0^{\mathrm{b}}$ & $1454 \pm 25.1^{\mathrm{b}}$ & $1537 \pm 26.3^{\mathrm{a}}$ & 0.0184 \\
Week 5 & $2177 \pm 29.3$ & $2122 \pm 31.5$ & $2100 \pm 33.8$ & $2103 \pm 31.9$ & $2123 \pm 33.4$ & $2157 \pm 35.2$ & 0.4381 \\
\hline
\end{tabular}

$\overline{\mathrm{a}, \mathrm{b} ;}$ Means within a row followed by different superscripts differ significantly $(\mathrm{p} \leq 0.05)$. SE: Standard Error, FA: Folic Acid, Glu: Glucose

Liu et al. (2016) found that the in-ovo injection of $150 \mu \mathrm{g}$ FA into the yolk sac after 11 days of embryonic age significantly increased the body weight of the one-day-old chickens. Liu et al. (2016) also reported that folic acid injection might up-regulate IGF2 expression, and they reported the genomic correlation between chickens' body weight and plasma IGF2 levels. The body weight of chickens in the (FA + Glu) group was significantly higher after two and four weeks than in the DPC group. These results partly agreed with the results reported by Nouri et al. (2018). They stated that body weight on day 21 was significantly improved in chickens that had been injected in-ovo with $120 \mu \mathrm{g}$ folic acid in albumen on the seventh day of incubation. Li et al. (2016) reported that body weight was significantly increased by the age of 42 days. Salmanzadeh (2012), Kanagaraju and Rathnapraba (2019) also indicated that in-ovo injection with $0.5 \mathrm{ml}$ of $25 \%$ glucose (on day-7 of incubation in the albumen and on day-18 of incubation in the amnion, respectively) improved body weight. Zhai et al. (2011c) found that injected chicken embryo in the amnion on day 19 of incubation with $0.1,0.4,0.7$, or $1.0 \mathrm{~mL}$ of various carbohydrates (Glucose, fructose, sucrose, maltose, and dextrin) associated with chicken's body weight. The recent results indicated that the combination of folic acid and glucose played an important role in poultry growth performance. An increases in the body weight of in-ovo-injected broiler embryos with (FA + Glu) could be viewed as a consequence of the improvement in enteric development and a subsequent enhancement in nutrient absorption (Zhai et al. 2011c), or as a good nutrient for better use of the energy by the embryos Uni et al. (2005).

Kanagaraju and Rathnapraba (2019) also stated that the in-ovo injection of $0.5 \mathrm{ml}$ of $25 \%$ glucose into the amnion on day 18 of incubation significantly improved duodenal, jejunal and ileal histomorphology (villi height, width, crypt depth, and villi surface area) of broilers, which led to the enhancement of digestion and absorption of nutrients. On other hand, Zhang et al. (2016) indicated that the individual injection of $0.4 \mathrm{~mL}$ glucose $(25 \mathrm{mg}$ ) on day 18 of the incubation did not affect hatching weight and growth performance of the chickens during the first week of post-hatching. The difference between Zhang et al. (2016) results and previous studies was related to the carbohydrate type, injection dose, genetic strain, and egg size.

The in-ovo injection had no significant effect on the daily feed intake at the age of one, two, three, and five weeks, the average daily feed intake and the total feed intake (Table 4). The only significant difference was observed at four 
weeks of age between DPC treatment and (FA + Glu) treatment, which consumed more food than the first one. The results of the present study were agreed with $\mathrm{Li}$ et al. (2016), who stated that there were no significant differences in the average daily feed intake between control and folic acid injected treatment. However, recent results did not agree with Nouri et al. (2018), they found that the feed intake of in-ovo chickens that were injected with folic acid was significantly increased compared to the control group. Salmanzadeh (2012) reported that the in-ovo injection of $0.5 \mathrm{ml}$ of $25 \%$ glucose into the albumen on day seven of incubation did not affect feed intake. Kanagaraju and Rathnapraba (2019) found that the treatment of in-ovo injection of $0.5 \mathrm{ml}$ of $25 \%$ glucose on day 18 of incubation into the amnion significantly increased feed intake compared to the negative control and positive groups. This discrepancy in the results might be due to the differences in injection time. In-ovo injection (shortly before hatching) with carbohydrates enabled the early adaptation of the avian gastrointestinal tract during embryonic development (Kucharska-Gaca et al., 2017) and adapted them to their new diet after hatching (Cardeal et al., 2015) in more feed intake.

Table 5 present that the in-ovo injection had no significant effects on the Feed Conversion Ratio (FCR) in any of the age group examined. In general, in-ovo injection with FA improved FCR insignificantly compared to (Glu) and (FA + Glu) treatments. The present results were partly agreed with Li et al. (2016), who found that injection treatment with 100 and $150 \mu \mathrm{g}$ folic acid significantly improved FCR. However, Nouri et al. (2018) stated that the FCR in broilers that had been injected with $120 \mu \mathrm{g}$ folic acid in albumen on day 7 of incubation was significantly improved on 0-42 days compared to the control treatment. On the other hand, Salmanzadeh (2012), Kanagaraju and Rathnapraba (2019) found that chickens that were injected with glucose in-ovo had a higher FCR than chickens hatched from the control group and the positive group.

No significant effect on weekly chickens' mortality was observed (Table 7). Injection treatments had no significant effect ( $p>0.05$ ) on the growth rate in all weeks (Table 6) and on the production number (Table 8). In-ovo injection of folic acid numerically increased the production number compared to the positive control.

Table 4. Impact of in-ovo injection of folic acid and glucose into albumen in freshly laid eggs from Arbor Acres broiler breeders on average daily feed intake $(\mathrm{g})$ (means \pm Standard Error) of broiler chickens.

\begin{tabular}{lccccccc}
\hline Age & $\begin{array}{c}\text { Negative } \\
\text { control }\end{array}$ & $\begin{array}{c}\text { Dry punch } \\
\text { control }\end{array}$ & $\begin{array}{c}\text { Positive } \\
\text { control }\end{array}$ & $\begin{array}{c}\text { Folic acid } \\
(0.2 \mathrm{mg} / \mathrm{egg})\end{array}$ & $\begin{array}{c}\text { Glucose } \\
(125 \mathrm{mg} / \mathrm{egg})\end{array}$ & $\begin{array}{c}\text { Folic acid and Glucose } \\
(0.2 \mathrm{mg} \text { FA+125 mg } \\
\text { Glu /egg })\end{array}$ & $\begin{array}{c}\text { p } \\
\text { value }\end{array}$ \\
\hline Week 1 & $23.3 \pm 0.7$ & $24.0 \pm 0.87$ & $23.3 \pm 0.9$ & $23.0 \pm 0.8$ & $22.9 \pm 0.8$ & $23.9 \pm 0.9$ & 0.9194 \\
Week 2 & $44.6 \pm 2.3$ & $42.5 \pm 2.6$ & $45.7 \pm 2.6$ & $41.4 \pm 2.5$ & $42.6 \pm 2.5$ & $44.7 \pm 2.6$ & 0.8282 \\
Week 3 & $94.6 \pm 2.3$ & $90.0 \pm 2.7$ & $87.7 \pm 2.7$ & $87.0 \pm 2.5$ & $89.1 \pm 2.5$ & $89.8 \pm 2.7$ & 0.2927 \\
Week 4 & $133.9 \pm 3.7^{\mathrm{a}}$ & $116.5 \pm 4.4^{\mathrm{b}}$ & $125.5 \pm 4.4^{\mathrm{ab}}$ & $124.3 \pm 4.1^{\mathrm{ab}}$ & $128.3 \pm 4.1^{\mathrm{ab}}$ & $135.2 \pm 4.4^{\mathrm{a}}$ & 0.0346 \\
Week 5 & $156.9 \pm 4.7$ & $147.8 \pm 5.6$ & $139.7 \pm 5.6$ & $145.3 \pm 5.2$ & $156.1 \pm 5.2$ & $151.6 \pm 5.6$ & 0.1802 \\
Average daily feed & $90.7 \pm 1.8$ & $84.1 \pm 2.2$ & $84.4 \pm 2.2$ & $87.8 \pm 2.0$ & $84.2 \pm 2.0$ & $89.1 \pm 2.2$ & 0.0934 \\
intake & $3173 \pm 64$ & $2945 \pm 76$ & $2954 \pm 76$ & $2947 \pm 71$ & $3073 \pm 71$ & $3117 \pm 76$ & 0.0934 \\
\hline
\end{tabular}

$\overline{\mathrm{a}, \mathrm{b} ;}$ Means within a row followed by different superscripts differ significantly $(\mathrm{p} \leq 0.05)$. SE: Standard Error, FA: Folic Acid, Glu: Glucose

Table 5. Impact of in-ovo injection of folic acid and glucose into albumen in freshly laid eggs from Arbor Acres broiler breeders on feed conversion (means \pm Standard Error) of broiler chickens.

\begin{tabular}{lccccccc}
\hline Age & $\begin{array}{c}\text { Negative } \\
\text { control }\end{array}$ & $\begin{array}{c}\text { Dry punch } \\
\text { control }\end{array}$ & $\begin{array}{c}\text { Positive } \\
\text { control }\end{array}$ & $\begin{array}{c}\text { Folic acid } \\
(0.2 \mathrm{mg} / \mathrm{egg})\end{array}$ & $\begin{array}{c}\text { Glucose } \\
(125 \mathrm{mg} / \mathrm{egg})\end{array}$ & $\begin{array}{c}\text { Folic acid and Glucose } \\
(0.2 \mathrm{mg} \text { FA+125 mg } \\
\text { Glu /egg })\end{array}$ & $\begin{array}{c}\text { p } \\
\text { value }\end{array}$ \\
\hline Week 1 & $1.31 \pm 0.04$ & $1.33 \pm 0.04$ & $1.34 \pm 0.04$ & $1.34 \pm 0.04$ & $1.35 \pm 0.04$ & $1.37 \pm 0.04$ & 0.9383 \\
Week 2 & $1.31 \pm 0.04$ & $1.32 \pm 0.04$ & $1.33 \pm 0.04$ & $1.29 \pm 0.04$ & $1.35 \pm 0.04$ & $1.24 \pm 0.04$ & 0.5759 \\
Week 3 & $1.40 \pm 0.02$ & $1.33 \pm 0.03$ & $1.33 \pm 0.03$ & $1.32 \pm 0.03$ & $1.35 \pm 0.03$ & $1.31 \pm 0.03$ & 0.1547 \\
Week 4 & $1.46 \pm 0.04$ & $1.37 \pm 0.05$ & $1.51 \pm 0.05$ & $1.45 \pm 0.04$ & $1.51 \pm 0.04$ & $1.50 \pm 0.04$ & 0.3017 \\
Week 5 & $1.67 \pm 0.05$ & $1.56 \pm 0.06$ & $1.52 \pm 0.06$ & $1.57 \pm 0.06$ & $1.62 \pm 0.06$ & $1.66 \pm 0.06$ & 0.4033 \\
$\mathbf{0 - 3 5}$ days & $1.49 \pm 0.03$ & $1.42 \pm 0.03$ & $1.50 \pm 0.03$ & $1.42 \pm 0.03$ & $1.49 \pm 0.03$ & $1.51 \pm 0.03$ & 0.1419 \\
\hline
\end{tabular}

No significant differences were observed. SE: Standard Error, FA: Folic Acid, Glu: Glucose

Table 6. Impact of in-ovo injection of folic acid and glucose into albumen in freshly laid eggs from Arbor Acres broiler breeders on growth rate (means \pm Standard Error) of broiler chickens. 


\begin{tabular}{lccccccc}
\hline Age & $\begin{array}{c}\text { Negative } \\
\text { control }\end{array}$ & $\begin{array}{c}\text { Dry punch } \\
\text { control }\end{array}$ & $\begin{array}{c}\text { Positive } \\
\text { control }\end{array}$ & $\begin{array}{c}\text { Folic acid } \\
(0.2 \mathrm{mg} / \mathrm{egg})\end{array}$ & $\begin{array}{c}\text { Glucose } \\
(125 \mathrm{mg} / \\
\text { egg })\end{array}$ & $\begin{array}{c}\text { Folic acid and Glucose } \\
(0.2 \mathrm{mg} \text { FA+125 mg } \\
\text { Glu /egg })\end{array}$ & $\begin{array}{c}\text { p } \\
\text { value }\end{array}$ \\
\hline Week 1 & $113.6 \pm 1.2$ & $113.6 \pm 1.4$ & $112.0 \pm 1.4$ & $110.2 \pm 1.4$ & $110.1 \pm 1.4$ & $111.9 \pm 1.5$ & 0.2695 \\
Week 2 & $79.2 \pm 2.9$ & $75.2 \pm 3.3$ & $81.9 \pm 3.3$ & $79.6 \pm 3.3$ & $78.4 \pm 3.3$ & $84.6 \pm 3.5$ & 0.4989 \\
Week 3 & $75.6 \pm 1.5$ & $75.5 \pm 1.7$ & $72.1 \pm 1.7$ & $74.1 \pm 1.7$ & $75.6 \pm 1.7$ & $72.7 \pm 1.8$ & 0.5210 \\
Week 4 & $53.0 \pm 1.0$ & $51.8 \pm 1.1$ & $50.7 \pm 1.1$ & $52.1 \pm 1.1$ & $51.9 \pm 1.1$ & $51.7 \pm 1.2$ & 0.7972 \\
Week 5 & $35.3 \pm 1.6$ & $37.6 \pm 1.8$ & $36.7 \pm 1.8$ & $37.1 \pm 1.8$ & $37.8 \pm 1.8$ & $33.4 \pm 1.9$ & 0.5453 \\
\hline
\end{tabular}

No significant differences were observed. SE: Standard Error, FA: Folic Acid, Glu: Glucose

Table 7. Impact of in-ovo injection of folic acid and glucose into albumen in freshly laid eggs from Arbor Acres broiler breeders on weekly chick mortality (means \pm Standard Error) of broiler chickens.

\begin{tabular}{|c|c|c|c|c|c|c|c|}
\hline Age & $\begin{array}{c}\text { Negative } \\
\text { control }\end{array}$ & $\begin{array}{c}\text { Dry punch } \\
\text { control }\end{array}$ & $\begin{array}{l}\text { Positive } \\
\text { control }\end{array}$ & $\begin{array}{c}\text { Folic acid } \\
(0.2 \mathrm{mg} / \mathrm{egg})\end{array}$ & $\begin{array}{c}\text { Glucose } \\
(125 \mathrm{mg} / \mathrm{egg})\end{array}$ & $\begin{array}{c}\text { Folic acid and Glucose } \\
(0.2 \mathrm{mg} \mathrm{FA}+125 \mathrm{mg} \\
\text { Glu /egg })\end{array}$ & $\begin{array}{c}\mathbf{p} \\
\text { value }\end{array}$ \\
\hline Week 1 & $0.76 \pm 0.36$ & $0.00 \pm 0.41$ & $0.00 \pm 0.41$ & $0.00 \pm 0.41$ & $0.00 \pm 0.41$ & $0.00 \pm 0.44$ & 0.6156 \\
\hline Week 2 & $1.95 \pm 0.83$ & $0.00 \pm 0.96$ & $0.00 \pm 0.96$ & $0.00 \pm 0.96$ & $2.35 \pm 0.96$ & $0.00 \pm 1.02$ & 0.2269 \\
\hline Week 3 & $1.04 \pm 0.49$ & $0.00 \pm 0.56$ & $0.00 \pm 0.56$ & $0.00 \pm 0.56$ & $0.00 \pm 0.56$ & $0.00 \pm 0.60$ & 0.6156 \\
\hline Week 4 & $0.00 \pm 0.38$ & $0.00 \pm 0.44$ & $1.11 \pm 0.44$ & $0.00 \pm 0.44$ & $0.00 \pm 0.44$ & $0.00 \pm 0.47$ & 0.3996 \\
\hline Week 5 & $0.00 \pm 1.39$ & $2.24 \pm 1.60$ & $4.69 \pm 1.60$ & $1.11 \pm 1.60$ & $1.23 \pm 1.60$ & $3.13 \pm 1.70$ & 0.3334 \\
\hline Sum & $3.75 \pm 1.65$ & $2.24 \pm 1.90$ & $5.80 \pm 1.90$ & $1.11 \pm 1.90$ & $3.58 \pm 1.90$ & $3.13 \pm 2.02$ & 0.6313 \\
\hline Survival rate & $96.3 \pm 1.6$ & $97.8 \pm 1.9$ & $94.2 \pm 1.9$ & $98.9 \pm 1.9$ & $96.4 \pm 1.9$ & $96.9 \pm 2.0$ & 0.6313 \\
\hline
\end{tabular}

No significant differences were observed, SE: Standard Error, FA: Folic Acid, Glu: Glucose

Table 8. Impact of in-ovo injection of folic acid and glucose into albumen in freshly laid eggs from Arbor Acres broiler breeders on production number (means \pm Standard Error) of broiler chickens.

\begin{tabular}{lcccccc}
\hline Age & $\begin{array}{c}\text { Negative } \\
\text { control }\end{array}$ & $\begin{array}{c}\text { Dry punch } \\
\text { control }\end{array}$ & $\begin{array}{c}\text { Positive } \\
\text { control }\end{array}$ & $\begin{array}{c}\text { Folic acid } \\
(0.2 \mathrm{mg} / \mathrm{egg})\end{array}$ & $\begin{array}{c}\text { Glucose } \\
(125 \mathrm{mg} / \mathrm{egg})\end{array}$ & $\begin{array}{c}\text { Folic acid and Glucose } \\
(0.2 \mathrm{mg} \text { FA+125 mg } \\
\text { Glu /egg })\end{array}$ \\
\hline PN & $397.1 \pm 14.2$ & $411.2 \pm 16.7$ & $371.0 \pm 16.7$ & $411.4 \pm 15.7$ & $386.4 \pm 15.7$ & $391.4 \pm 16.7$ \\
\hline
\end{tabular}

No significant differences were observed, SE: Standard Error, FA: Folic Acid, Glu: Glucose

\section{Carcass characteristics}

The effects of in-ovo injection treatments of hatching eggs on carcass characteristics are present in figure 1 and figure 2. Injection treatments had a significant effect on dressing percentage ( $p>0.05)$. In-ovo injection of FA and (FA + Glu) resulted in a higher dressing percentage compared to the positive control group. Also, the in-ovo injection of (FA + Glu) resulted in a significantly higher percentage of front parts compared to the positive control. The percentage of hind parts was significantly higher due to the in-ovo injection of FA compared to the DPC treatment. No significant effects were observed on carcass meat percentage (Figure 2). The percentage of Liver, heart and total giblet was not significantly affected by any injection treatments (Table 9). However, the gizzard percentage was significantly lower in the negative control groups than in all other groups with the exception of the DPC._The in-ovo injection of (FA + Glu) resulted in a significantly higher in percentage of proventriculus than the negative control, the positive control and the folic acid injection group. Likewise, the intestinal diameter of the (FA + Glu) treatment was significantly wider than the rest of the treatments. Folic acid, glucose, and $(\mathrm{FA}+\mathrm{Glu})$ treatments had a significantly shorter intestine than the negative control group (Table 9). The percentage of all lymphoid organs (spleen, bursa, and thymus) was not significantly affected by in-ovo injection treatments (Table 10). 


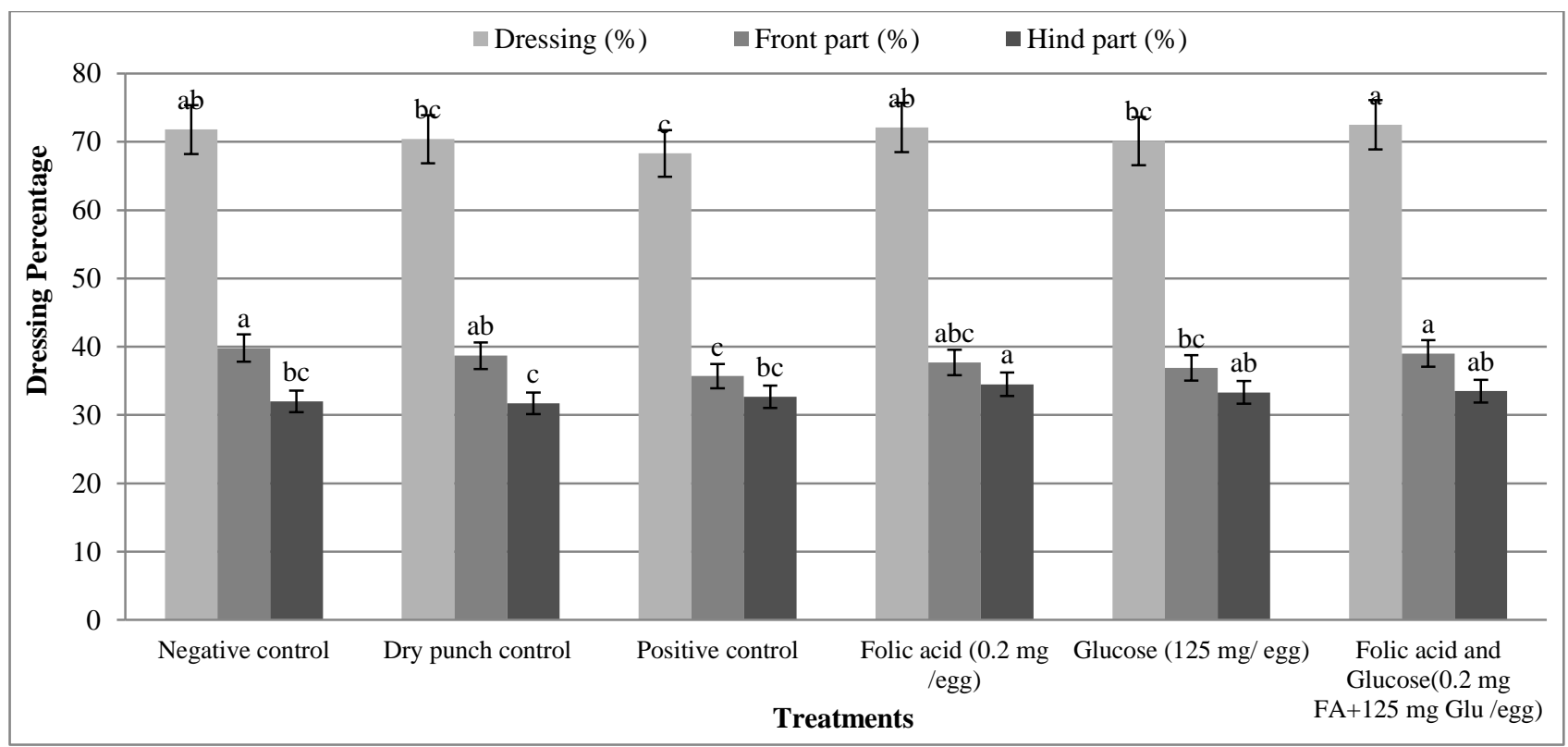

Figure 1. Impact of in-ovo injection of folic acid and glucose into albumen in freshly laid eggs from Arbor Acres broiler parents on carcass dressing as a percentage of living body weight of broiler chickens.

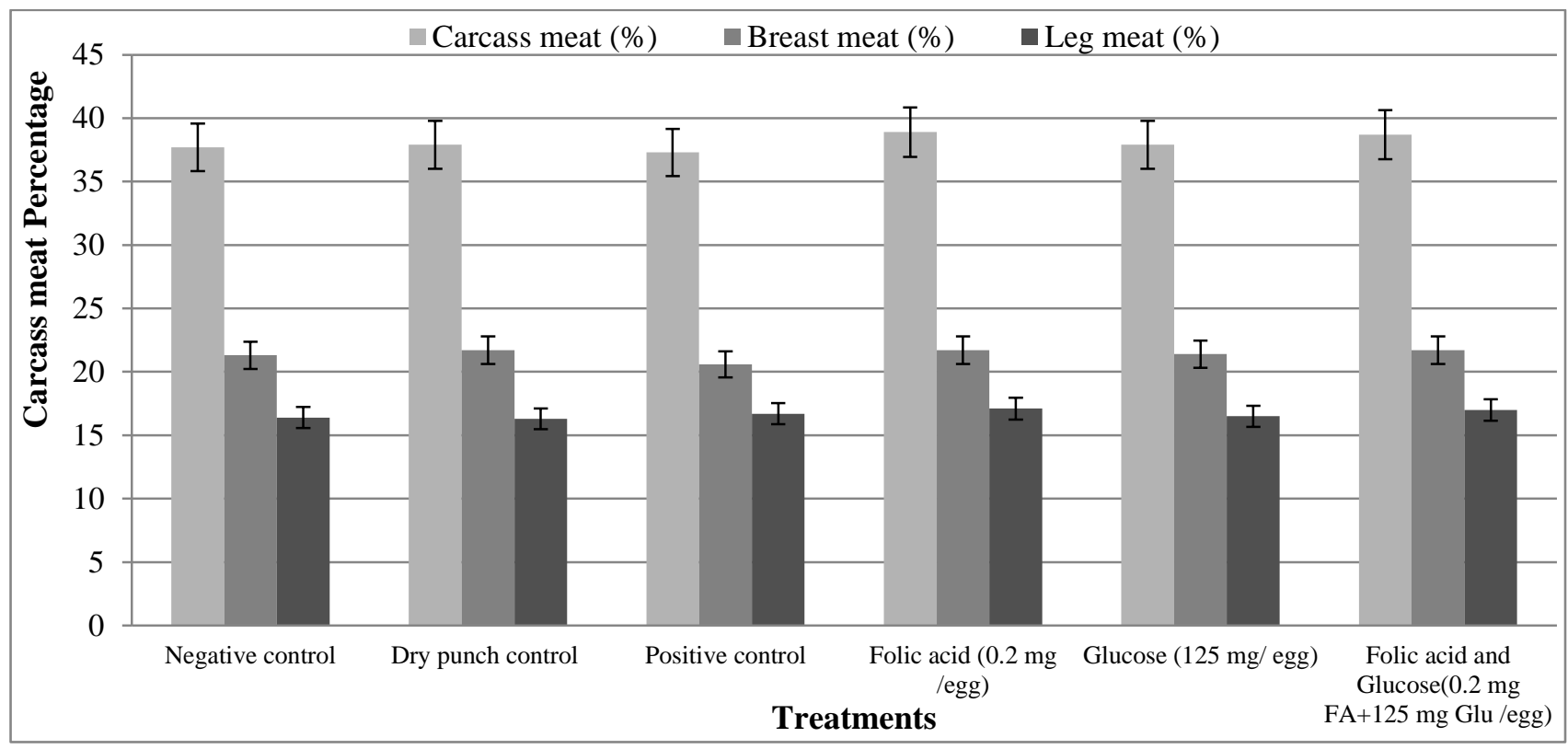

Figure 2. Impact of in-ovo injection of folic acid and glucose into albumen in freshly laid eggs from Arbor Acres broiler breeders on carcass dressing as percentage of living body weight of broiler chickens.

Table 9. Impact of in-ovo injection of folic acid and glucose into albumen in freshly laid eggs from Arbor Acres broiler breeders on giblets as percentage to live body weight (means \pm Standard Error) of broiler chickens.

\begin{tabular}{|c|c|c|c|c|c|c|c|}
\hline Items & $\begin{array}{l}\text { Negative } \\
\text { control }\end{array}$ & $\begin{array}{l}\text { Dry punch } \\
\text { control }\end{array}$ & $\begin{array}{l}\text { Positive } \\
\text { control }\end{array}$ & $\begin{array}{c}\text { Folic acid } \\
(0.2 \mathrm{mg} / \mathrm{egg})\end{array}$ & $\begin{array}{c}\text { Glucose } \\
(125 \mathrm{mg} / \mathrm{egg})\end{array}$ & $\begin{array}{c}\text { Folic acid and } \\
\text { Glucose }(0.2 \mathrm{mg} \\
\text { FA+125 mg Glu /egg })\end{array}$ & $\begin{array}{c}\mathbf{p} \\
\text { value }\end{array}$ \\
\hline Liver (\%) & $2.29 \pm 0.08$ & $2.44 \pm 0.09$ & $2.34 \pm 0.09$ & $2.12 \pm 0.09$ & $2.29 \pm 0.08$ & $2.35 \pm 0.08$ & 0.1868 \\
\hline Heart (\%) & $0.50 \pm 0.02$ & $0.58 \pm 0.02$ & $0.52 \pm 0.02$ & $0.57 \pm 0.02$ & $0.51 \pm 0.02$ & $0.55 \pm 0.02$ & 0.0765 \\
\hline Gizzard (\%) & $1.59 \pm 0.11^{\mathrm{b}}$ & $1.91 \pm 0.11^{\mathrm{ab}}$ & $2.12 \pm 0.11^{\mathrm{a}}$ & $1.93 \pm 0.11^{\mathrm{a}}$ & $2.09 \pm 0.11^{\mathrm{a}}$ & $2.05 \pm 0.11^{\mathrm{a}}$ & 0.0168 \\
\hline Giblet (\%) & $4.39 \pm 0.17$ & $4.92 \pm 0.18$ & $4.98 \pm 0.18$ & $4.62 \pm 0.18$ & $4.99 \pm 0.17$ & $4.95 \pm 0.17$ & 0.0695 \\
\hline Proventriculus (\%) & $0.45 \pm 0.03^{b}$ & $0.55 \pm 0.03^{\mathrm{ab}}$ & $0.47 \pm 0.03^{b}$ & $0.46 \pm 0.03^{\mathrm{b}}$ & $0.54 \pm 0.03^{\mathrm{ab}}$ & $0.59 \pm 0.03^{\mathrm{a}}$ & 0.0144 \\
\hline $\begin{array}{l}\text { Length of intestine } \\
\text { (cm) }\end{array}$ & $189.8 \pm 5.4^{\mathrm{a}}$ & $174.2 \pm 5.7^{\mathrm{ab}}$ & $173.7 \pm 5.7^{\mathrm{ab}}$ & $164.7 \pm 5.7^{b}$ & $168.3 \pm 5.4^{b}$ & $163.0 \pm 5.4^{b}$ & 0.0150 \\
\hline $\begin{array}{l}\text { Diameter of intestine } \\
(\mathrm{cm})\end{array}$ & $1.13 \pm 0.040^{\mathrm{b}}$ & $1.07 \pm 0.042^{b}$ & $1.16 \pm 0.042^{b}$ & $1.11 \pm 0.042^{b}$ & $1.10 \pm 0.040^{\mathrm{b}}$ & $1.28 \pm 0.040^{\mathrm{a}}$ & 0.0097 \\
\hline
\end{tabular}

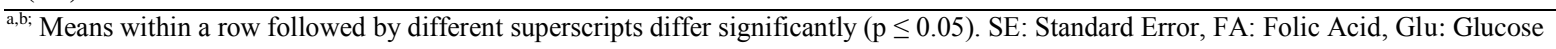


Table 10. Impact of in-ovo injection of folic acid and glucose into albumen in freshly laid eggs from Arbor Acres broiler breeders on lymphoid organs as percentage to live body weight (means \pm Standard Error) of broiler chickens.

\begin{tabular}{|c|c|c|c|c|c|c|c|}
\hline Items & $\begin{array}{c}\text { Negative } \\
\text { control }\end{array}$ & $\begin{array}{c}\text { Dry punch } \\
\text { control }\end{array}$ & $\begin{array}{c}\text { Positive } \\
\text { control }\end{array}$ & $\begin{array}{c}\text { Folic acid } \\
(0.2 \mathrm{mg} / \mathrm{egg})\end{array}$ & $\begin{array}{c}\text { Glucose } \\
(125 \mathrm{mg} / \mathrm{egg})\end{array}$ & $\begin{array}{c}\text { Folic acid and } \\
\text { Glucose }(0.2 \mathrm{mg} \\
\text { FA+125 mg Glu /egg) }\end{array}$ & $\begin{array}{c}\mathbf{p} \\
\text { value }\end{array}$ \\
\hline Spleen (\%) & $0.10 \pm 0.01$ & $0.14 \pm 0.01$ & $0.11 \pm 0.01$ & $0.11 \pm 0.01$ & $0.12 \pm 0.01$ & $0.14 \pm 0.01$ & 0.1206 \\
\hline Bursa (\%) & $0.14 \pm 0.02$ & $0.20 \pm 0.02$ & $0.20 \pm 0.02$ & $0.15 \pm 0.02$ & $0.14 \pm 0.02$ & $0.16 \pm 0.02$ & 0.0985 \\
\hline Thymus (\%) & $0.69 \pm 0.03$ & $0.71 \pm 0.03$ & $0.64 \pm 0.03$ & $0.62 \pm 0.03$ & $0.63 \pm 0.03$ & $0.66 \pm 0.03$ & 0.3642 \\
\hline
\end{tabular}

The present results agreed with Abd El-Azeem et al. (2014), who reported that in-ovo injection of FA significantly increased the carcass percentage of broilers, referring this effect to the anabolic effect of the treatments on muscle gain. Nouri et al. (2018) stated that there were no significant differences in the carcass characteristics of broilers in-ovo that were injected with FA $(40,80$, and $120 \mu \mathrm{g})$ compared to the control group at the age of 42 days. Also, Abdel-Fattah and Shourrap (2012) reported that in-ovo injection of FA significantly increased the weight of the breast muscles of chickens at hatching and at 42 days of age. Furthermore, the positive effects of using FA on breast meat yield reflected its advantageous use in enhancement broilers carcass meat yield (Abdel-Fattah and Shourrap, 2012).

Previous studies indicated that in-ovo injection of carbohydrates enhanced muscle yield. The intra yolk sac injection of dextrose may have motivated the release of insulin, which might have increased the use of protein metabolically (Tasharofi et al., 2018). Salmanzadeh et al. (2011) found that in-ovo injection of glucose after seven days of incubation could improve the percentage of carcass and breast. Salmanzadeh et al. (2011) stated that in-ovo injection of glucose at 42 days of age had no significant effect on the liver, heart and gizzard of broiler chickens.

The results of current research revealed that the injection treatment of $(F A+G l u)$ significantly increased the dressing percentage, front parts and hind parts. Previous studies demonstrated that the in-ovo injection of carbohydrate solutions or carbohydrates in combination with other nutrients (e.g., $\beta$-hydroxy- $\beta$-methylbutyrate) could increase breast muscle weight in broilers by six to eight percent up to 25 days post-hatching (Uni et al., 2005). Zhang et al. (2016) reported that the combined injection of six $\mathrm{mg}$ creatine monohydrate with $25 \mathrm{mg}$ glucose on 18 day of incubation in the amnion had a synergistic effect on the enhancement of embryo energy status and the increase of the muscle creatine and phosphocreatine concentrations. Therefore, Zhang et al. (2016) concluded that it would be useful for improving embryonic development, and then improving chicken growth. Salmanzadeh et al. (2012) reported that glucose and glucose with magnesium in-ovo injection significantly increased the breast muscle size; they refer this effect to the hypothesis that an exogenous dietary supplement could substitute glucose with amino acids from the pectoral muscle. In other words, the exogenous supplies of nutrients increase protein deposition, probably by reducing muscle wasting. $\underline{\text { Salmanzadeh et al. (2012) }}$ also reported that the in-ovo injection of glucose and glucose with magnesium resulted in increased carcass and gizzard yields compared to the negative control and the positive control group. However,

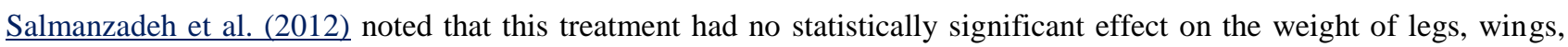
neck, liver and heart of broiler chickens (Salmanzadeh et al., 2012).

\section{CONCLUSION}

In conclusion, the in-ovo injection of folic acid decreases the albumen $\mathrm{pH}$ after four days of injection in the eggs from older breeder. The in-ovo injection of folic acid or glucose treatments had no significant effect on the hatchability of the fertile eggs. On the other hand, in-ovo injection with a combination of folic acid and glucose had significantly positive effects on chickens' body weight at two and four weeks of age and dressing percentage, without affecting the feed intake and feed conversion ratio. No significant differences were observed on chickens' mortality, growth rate and production number in all injection treatment groups. It could be concluded that studies on the best time, volume, and the site of folic acid and glucose injection are also needed.

\section{DECLARATIONS}

\section{Authors' contribution}

Fatma Rasmy Mohamed and Hassan Bayoumi Gharib designed the curriculum and facilitate the experimental work; Mohamed Abdel-Rahman El-menawey performed the experimental statistical analyzes. Amal Ahmed AbdelHalim applied the practical part of the study, tabulated the experimental data and wrote the research article. All authors have revised the manuscript.

\section{Competing interests}

The authors have no competing interests. In addition, we have no authorship or article publication conflict. 


\section{Consent to publish}

All the authors approved and agreed to publish the manuscript.

\section{REFERENCES}

Abd El-Azeem, Nafisa A, Marwa Sh Abdo, Madkour M, and El-Wardany I (2014). Physiological and histological responses of broiler chicks to in ovo injection with folic acid or 1-carnitine during embryogenesis. Global Veterinaria, 13(4): 544-551. DOI: https:// https://doi.org/10.5829/idosi.gv.2014.13.04.85231

Abdel-Fattah SA and Shourrap MI (2012). Physiological effects of in ovo L carnitine and embryonic thermal conditioning on pre and posthatch development of broiler chicks. In 3rd Mediterranean Poultry Summit and $6^{\text {th }}$ international Poultry Conference, pp. 26-29. Available at: https://www.researchgate.net/profile/Mohamed_Shourrap/publication/316441817

Akhlaghi A, Ahangari YJ, Hashemi SR, Navidshad B, Pirsaraei ZA, Deldar H and Liang JB (2013). Prestorage in ovo injection of biological buffers: An approach to improve hatchability in long-term stored eggs. Poultry science, 92(4): 874-881. DOI: https://doi.org/10.3382/ps.2012-02610

Bellairs R, and Osmond M (2005). Atlas of chick development. Elsevier. Available at: https://books.google.com.eg/books?hl=en\&lr=\&id=UDCUi8cHWEwC\&oi

Bennett CD (1992). The influence of shell thickness on hatchability in commercial broiler breeder flocks. Journal of Applied Poultry Research, 1(1): 61-65. DOI: https://doi.org/10.1093/japr/1.1.61

Cardeal PC, Caldas EOL, Lara LJC, Rocha JSR, Baiao NC, Vaz DP and da Silva Martins NR (2015). In ovo feeding and its effects on performance of newly-hatched chicks. World's Poultry Science Journal, 71(4): 655-662. DOI: https://doi.org/10.1017/S0043933915002445

Christensen VL, Donaldson WE and McMurtry JP (1996). Physiological differences in late embryos from turkey breeders at different ages. Poultry science, 75(2): 172-178. DOI: https://doi.org/10.3382/ps.0750172

Combs JrGF and McClung JP (2016). The vitamins: fundamental aspects in nutrition and health. Academic press. Available at: https://books.google.com.eg/books?hl=en\&lr=\&id=UEy0DAAAQBAJ\&oi

Duncan DB (1955). Multiple ranges, and multiple F tests. Biometrics, 11: 1-42. Available at: https://www.jstor.org/stable/3001478?seq=1

Ebrahimi MR, Ahangari YJ, Zamiri MJ, Akhlaghi A, and Atashi H (2012). Does preincubational in ovo injection of buffers or antioxidants improve the quality and hatchability in long-term stored eggs? Poultry science, 91(11): 2970-2976. DOI: https://doi.org/10.3382/ps.2012-02246

Elibol O, Peak SD, and Brake J (2002). Effect of flock age, length of egg storage, and frequency of turning during storage on hatchability of broiler hatching eggs. Poultry science, 81(7): 945-950. DOI: https://doi.org/10.1093/ps/81.7.945

Iqbal J, Khan SH, Mukhtar N, Ahmed T, and Pasha RA (2016). Effects of egg size (weight) and age on hatching performance and chick quality of broiler breeder. Journal of applied animal research, 44(1): 54-64. DOI: https://doi.org/10.1080/09712119.2014.987294

Kanagaraju P, and Rathnapraba S (2019). Effect of in-ovo injection of glucose and egg white protein on the production performance and gut histomorphometry of broiler chicken. Indian Journal of Animal Research, 53(5): 675-679. DOI: http://dx.doi.org/10.18805/ijar.B-3555

Koppenol A, Delezie E, Wang Y, Franssens L, Willems E, Ampe B, and Everaert N (2015). Effects of maternal dietary EPA and DHA supplementation and breeder age on embryonic and post-hatch performance of broiler offspring: Age and n-3 pufa affect embryonic and posthatch performance. Journal of animal physiology and animal nutrition, 99: 36-47. DOI: https://doi.org/10.1111/jpn.12308

Kucharska-Gaca J, Kowalska E, and Debowska M (2017). In ovo feeding-technology of the future-a review. Annals of Animal Science, 17(4): 979992. DOI: https://doi.org/10.1515/aoas-2017-0004

Lapao C, Gama LT, and Soares MC (1999). Effects of broiler breeder age and length of egg storage on albumen characteristics and hatchability. Poultry science, 78(5): 640-645. DOI: https://doi.org/10.1093/ps/78.5.640

Li S, Zhi L, Liu Y, Shen J, Liu L, Yao J, and Yang X (2016). Effect of in ovo feeding of folic acid on the folate metabolism, immune function and epigenetic modification of immune effector molecules of broiler. British Journal of Nutrition, 115(3): 411-421. DOI: https://doi.org/10.1017/S0007114515004511

Liu Y, Zhi L, Shen J, Li S, Yao J, and Yang X (2016). Effect of in ovo folic acid injection on hepatic IGF2 expression and embryo growth of broilers. Journal of animal science and biotechnology, 7(1): 40. DOI: https://doi.org/10.1186/s40104-016-0099-3

Meijerhof R (1994). Theoretical and empirical studies on temperature and moisture loss of hatching eggs during the pre-incubation period. Available at: https://library.wur.nl/WebQuery/wurpubs/fulltext/205157

Narushin VA, and Romanov MN (2002). Egg physical characteristics and hatchability. World's Poultry Science Journal, 58(3): 297-303. DOI: https://doi.org/10.1079/WPS20020023

Nouri S, Ghalehkandi JG, Hassanpour S, and Aghdam-Shahryar H (2018). Effect of in ovo feeding of folic acid on subsequent growth performance and blood constituents' levels in broilers. International Journal of Peptide Research and Therapeutics, 24(3): 463-470. DOI: https://doi.org/10.1007/s10989-017-9629-X

Parnian A, Navidshad B, Mirzaei F, Behmaram R, and Deldar H (2019). Effect of in ovo injection of nicotonic acid, pantothenic acid or folic acid on immune system and growth of broiler chickens. Iranian Journal of Veterinary Medicine, 13(4): 411-420. DOI: https://dx.doi.org/10.22059/ijvm.2019.278345.1004976

Peebles ED, Doyle SM, Zumwalt CD, Gerard PD, Latour MA, Boyle CR, and Smith TW (2001). Breeder age influences embryogenesis in broiler hatching eggs. Poultry Science, 80(3): 272-277. DOI: https://doi.org/10.1093/ps/80.3.272

Reijrink IAM, Meijerhof R, Kemp B, and Van Den Brand H (2008). The chicken embryo and its micro environment during egg storage and early incubation. World's Poultry Science Journal, 64(4): 581-598. DOI: https://doi.org/10.1017/S0043933908000214

Ricks CA, Avakian A, Bryan T, Gildersleeve R, Haddad E, Ilich R, and Whitfill C (1999). In ovo vaccination technology. Advances in veterinary medicine, 41: 495-515. Available at: https://pubmed.ncbi.nlm.nih.gov/9890038/

Robel EJ (2002). Assessment of dietary and egg injected d-biotin, pyridoxine and folic acid on turkey hatchability: folic acid and poultry weight. World's Poultry Science Journal, 58(3): 305-315. DOI: https://doi.org/10.1079/WPS20020024

Salmanzadeh M, Nezhad YE, Shahryar HA, Ashrafi S, Moghaddam PP, and Lotfi A (2011). The effects of in ovo administration of glucose on carcass characterizes of broiler chickens. Global Veterinária, 6(5): 429-432. Available at: http://www.idosi.org/gv/gv6(5)11/1.pdf

Salmanzadeh M, Ebrahimnezhad Y, Shahryar HA, and Beheshti R (2012). The effects of in ovo injection of glucose and magnesium in broiler breeder eggs on hatching traits, performance, carcass characteristics and blood parameters of broiler chickens. Arch. Geflugelkunde, 76: $277-284$. Available at: https://www.cabdirect.org/cabdirect/abstract/20123387531

Salmanzadeh M (2012). The effects of in-ovo injection of glucose on hatchability, hatching weight and subsequent performance of newly-hatched 
Starck JM and Ricklefs RE (Eds.) (1998). Avian growth and development: evolution within the altricial-precocial spectrum (No. 8). Oxford University Press on Demand, Available at: https://books.google.com.eg/books?hl=en\&lr=\&id=A0HB7Mq41OYC\&oi

Tasharofi S, Mohammadi F, Amiri N, and Nazem MN (2018). Effects of intra-yolk-sac injection of dextrose and albumin on performance, jejunum morphology, liver and pectoral muscle glycogen and some serum metabolites of broilers. Journal of animal physiology and animal nutrition, 102(4): 917-923. DOI: https://doi.org/10.1111/jpn.12882

Tona K, Onagbesan O, De Ketelaere B, Decuypere E, and Bruggeman V (2004). Effects of age of broiler breeders and egg storage on egg quality, hatchability, chick quality, chick weight, and chick posthatch growth to forty-two days. Journal of Applied Poultry Research, 13(1): 10-18. DOI: https://doi.org/10.1093/japr/13.1.10

Ulmer-Franco AM, Fasenko GM, and Christopher EEOD (2010). Hatching egg characteristics, chick quality, and broiler performance at 2 breeder flock ages and from 3 egg weights. Poultry science, 89(12): 2735-2742. DOI: https://doi.org/10.3382/ps.2009-00403

Uni Z, Ferket PR, Tako E, and Kedar O (2005). In ovo feeding improves energy status of late-term chicken embryos. Poultry Science, 84(5): 764-770. DOI: https://doi.org/10.1093/ps/84.5.764

Vieira AR, Murray JC, Trembath D, Orioli IM, Castilla EE, Cooper ME, and Speer M (2005). Studies of reduced folate carrier 1 (RFC1) A80G and 5 , 10-methylenetetrahydrofolate reductase (MTHFR) C677T polymorphisms with neural tube and orofacial cleft defects. American Journal of Medical Genetics Part A, 135(2): 220-223. DOI: https://doi.org/10.1002/ajmg.a.30705

Vieira SL (2007). Chicken embryo utilization of egg micronutrients. Brazilian Journal of Poultry Science, 9(1): 1-8. DOI: https://doi.org/10.1590/S1516-635X2007000100001

XLSTAT (2014). Statistical software for MS Excel. statiscal and data analysis with MS Excel Addinsoft 224 Centre Street, 3rd floor New York, Ny10013 USA. Available at: https://www.xlstat.com/en/news/xlstat-2014-5

Zhai W, Bennett LW, Gerard PD, Pulikanti R and Peebles ED (2011a). Effects of in ovo injection of carbohydrates on somatic characteristics and liver nutrient profiles of broiler embryos and hatchlings. Poultry science, 90(12): 2681-2688. DOI: https://doi.org/10.3382/ps.2011-01532

Zhai W, Gerard PD, Pulikanti R and Peebles ED (2011b). Effects of in ovo injection of carbohydrates on embryonic metabolism, hatchability, and subsequent somatic characteristics of broiler hatchlings. Poultry science, 90(10): 2134-2143. DOI: https://doi.org/10.3382/ps.2011-01418

Zhai W, Rowe DE and Peebles ED (2011c). Effects of commercial in ovo injection of carbohydrates on broiler embryogenesis. Poultry science, 90(6): 1295-1301. DOI: https://doi.org/10.3382/ps.2010-01130

Zhang L, Zhu XD, Wang XF, Li JL, Gao F, and Zhou GH (2016). Individual and combined effects of in-ovo injection of creatine monohydrate and glucose on somatic characteristics, energy status, and post-hatch performance of broiler embryos and hatchlings. Poultry science, 95(10): 23522359. DOI: https://doi.org/10.3382/ps/pew130

Zhang H, Elliott KEC, Durojaye OA, Fatemi SA, Schilling MW, and Peebles ED (2019). Effects of in ovo injection of L-ascorbic acid on growth performance, carcass composition, plasma antioxidant capacity, and meat quality in broiler chickens. Poultry science, 98(9): 3617-3625. DOI: http://dx.doi.org/10.3382/ps/pez173 